\title{
Phytochemicals from Ficus sycomorus L. leaves act as insecticides and acaricides
}

\author{
Romeh, A. A. \\ Plant Production Department, Faculty of Technology and Development, Zagazig University, Zagazig, Egypt. \\ Accepted 17 June, 2013
}

\begin{abstract}
Phytophagus insects cause damage and economic loss in crops. The indiscriminate application of synthetic products has led to various problems. Among all, bioactive natural compounds considered to have an activity because of the presence of several chemicals that can exert their activities both as fumigants and by direct contact. The bioactive phytochemicals from Ficus sycomorus leaves were analyzed by gas chromatography - mass spectrometry (GC-MS). Insecticidal and acaricidal of the bioactive components were also determined. Results show that the chemical analysis of vaporous from $F$. sycomorus leaves allowed identification of 1, 2 benzenedicarboxilic acid, diisooctyl ester $(45.06 \%)$, n-Hexadecanoic acid (7.67), 1H-pyrazole,4-Nitro (5.13), 3-Hexen-1- ol, benzoate,Z (4.57), oleic acid (4.30), hexanedioic acid, bis (2-ethyl hexyl) ester (4.15), methyl oleate (2.41), 3- buten- 2-one, 4-(2, 6, 6trimethyl-1-cyclohexen-1-yl) (2.08), 9- octadecenoic acid (Z)- 2-hydroxy-1-(hydroxymethyl) ethyl ester (1.79), benzene methanol (1.59), Cycloheptasiloxane,tetradecamethyl (1.38), Z, Z- 3, 13- octadecadien-1ol (1.31), 2- pentadecanone (1.27), 1-methylbicyclo [4.1.0] heptanes 1-methylnorcarane (1.06), L- linalool (1.04), cyclohexene (1.03) and methyl jasmonate (0.94) as main parts. The bioactive phytochemicals from $F$. sycomorus leaves were reported to be more toxic as the fumigant toxicity tests than the contact phase to the tested insects. The concentrations at $0.1,0.01$ and $0.001 \%$ were found to be repellent to adult females of Tetranychus utricae, followed by Aphis craccivora and Sitophilus oryzae, respectively. Here we demonstrate that bioactive phytochemicals from $F$. sycomorus leaves have a wide range of insecticidal and acaricidal and could become an alternative to synthetic pesticides for controlling certain important insects and mites.
\end{abstract}

Key words: Ficus sycomorus leaves, gas chromatography - mass spectrometry (GC-MS), Sitophilus oryzae, Aphis craccivora, Tetranychus urticae.

\section{INTRODUCTION}

In recent years, scientists have focused on the increase of food production needed for the fast expansion of the world population. Unfortunately, large yield losses occur because of insects and plant diseases caused by fungi, bacteria and viruses (Fletcher et al., 2006). Crop loss because of insect pests varies between 10 and $30 \%$ for major crops (Kordali et al., 2008). Sitophilus species are serious cosmopolitan pests of stored grain (Liu and Ho, 1999). Rice weevil (Sitophilus oryzae L.) is the main representatives of this genus, which principally attack rice (Oryza sativa L.), maize (Zea mays L.), wheat (Triticum sativum Lam.), and sorghum (Sorghum bicolor (L.) Moench) among others, through direct feeding on grain kernels causing unfavorable effects on food quality, safety, and preservation (Rajendran and Sriranjini, 2008). The two-spotted spider mite, Tetranychus urticae Koch, is one of the most important pests of fruits, vegetable and ornamental plants and worldwide (Aslan et al., 2004). 
The mite has been reported to attack about 1200 species of plants of which more than 150 are economically important (Zhang, 2003). Spider mites have evolved resistance to more than 80 acaricides so far, and resistance has been reported from more than 60 countries (Pontes et al., 2007). Aphis craccivora Koch, (Aphididae), commonly known as black cowpea aphid, is one of the most important polyphagous insect-pests that colonizes, with a marked preference for legumes, plant hosts belonging to families Cruciferae, Cucurbitaceae, Asteraceae and Fabaceae throughout the world (Palumbo and Tickes, 2001). Synthetic insecticides and fumigants are widely used to control pests. However, the indiscriminate application of synthetic products has led to various problems including toxic residues in treating products, environmental pollution, and resistance against pesticides ( $Y e$ et al., 2010). Therefore, because of increasing drawbacks of the continued use of conventional fumigants, an effort is needed to develop new alternative pesticides to replace those being currently used.

Biofumigants have received much attention as pest control agents due to the presence of several modes of action, including insecticides, repellent or antifeedant properties (Viuda-Martos et al., 2010). Also, these products do not leave harmful residue to the environment, low toxicity in warm-blooded animals, high volatility and have medicinal properties for human, with lower toxicity to mammals (Cosimi et al., 2009). The search for new plant species with insecticide properties has been increasing in the past few years because of the indiscriminate use of synthetic pesticides for crop protection. Among bioactive natural compounds, several plant essential oils and plant extracts considered to have an activity because of the presence of several chemicals that can exert their activities both as fumigants and by direct contact. These active insecticide, repellent, antifeedant, and insect growth regulatory properties (Santos et al., 2011; Safia and Aoumeur, 2011).

Plants synthesize a broad range of secondary metabolites, including alkaloids and terpenoids, which are toxic to herbivores and pathogens, and so are believed to act as defense compounds (Wittstock and Gershenzon, 2002). These compounds can reduce insect development, interfere with digestion, and finanly kill them (Navia-Gine' et al., 2009).

Ficus sycomorus L., a medicinal plant belonging to the family Moraceae comprises about 755 fig tree species worldwide (Van Noort et al., 2007). F. sycomorus L. is widely distributed in tropical West Africa and grown in the Mediterranean basin of Egypt since antiquity and is known for their medicinal and aromatic properties (George and Lawrences, 1961). Phytochemical investigations on a few Ficus spp. were undertaken and led to identification of over 100 compounds. Most of these compounds are phenanthroindolizidine alkaloids from the leaves and stems of Ficus hispida and
Ficus septica (Gao et al., 2004). Several coumarins were isolated from several different Ficus spp. (Chang et al., 2005) and multiple flavonoids have been identified from Ficus spp. stems, leaves, and roots (Li et al., 2007). Also, prominent were triterpenoids from the roots, leaves (Teixeira et al., 2006). Also, 54 different triacylgylcerols were identified in Ficus carica seed oil using mass spectrometry (Holcapek et al., 2005).

Yet, no reports were published about the volatile parts of $F$. sycomorus $L$. leaves as potential pesticides. Therefore, the aim of this study is to identify the chemical composition of $F$. sycomorus leaves by gas chromatography - mass spectrometry (GC-MS), and evaluate the fumigant, contact toxicity and repellency as an alternative to chemical insecticide against adult $S$. oryzae, $A$. cracccivora, and adult females of $T$. urticae under laboratory conditions.

\section{MATERIALS AND METHODS}

\section{Plant materials}

Leaves of $F$. sycomorus were collected in the middle of May 2012 from Aboutouala, Mania El-kamh province, Sharkia governorate, Egypt. The leaves were randomly collected from plant parts and shade dried. The plant material was dried naturally on laboratory benches at room temperature $\left(28-30^{\circ} \mathrm{C}\right)$ for 5 days until crisp.

\section{Isolation of volatiles from $F$. sycomorus leaves}

A hundred grams of Sycamore leaves were placed in a flask and $400 \mathrm{ml}$ of distilled water was added. Sycamore leaves were extracted by hydrodistillation using a Clevenger-type apparatus for $4 \mathrm{~h}$. Water was heated to produce steam that carried the most volatile fractions of the aromatic material with it. The watery phase was extracted with dichloromethane $(3 \times 50 \mathrm{ml})$ and dried with anhydrous sodium sulphate. The dichloromethane solution of the volatiles was concentrated to $5 \mathrm{ml}$ by evaporation under vacuum in a rotary evaporator at $30^{\circ} \mathrm{C}$ under reduced pressure. The volatile phase from $F$. sycomorus leaves was stored at $4^{\circ} \mathrm{C}$ prior to further analyses. The volatile phase in dichloromethane was performed for gas chromatography and mass spectrometry analysis. The volatiles yield calculated about the dry matter.

\section{Gas chromatography-mass spectrometry analysis (GC/MS)}

Volatile compound analysis was performed with a gas chromatography system (Aglient 6890 GC) with an Agilent mass spectrometric detector, with a direct capillary interface and fused silica capillary column HP-5 MS $(30 \mathrm{~m} \times 0.32 \mathrm{~mm} \times 0.25 \mu \mathrm{m}$ film thickness).

Helium was used as the carrier gas at a flow about $1.0 \mathrm{ml} / \mathrm{min}$ pulsed splitless. The solvent delay was $3 \mathrm{~min}$. and the injection size was $1.0 \mu \mathrm{l}$. The mass spectrometric detector was operated in an electron impact ionization mode with an ionizing energy of $70 \mathrm{eV}$. Scanning from $\mathrm{m} / \mathrm{z} 50$ to 500 and the ion source temperature was $230^{\circ} \mathrm{C}$. The electron multiplier voltage (EM voltage) was maintained $1250 \mathrm{v}$ above auto tune. The instrument was manually turned using perfluorotributyl amine (PFTBA). Oven temperature program at $45^{\circ} \mathrm{C}(2 \mathrm{~min}), 150^{\circ} \mathrm{C}(5 \mathrm{~min})$ at a rate of $2^{\circ} \mathrm{C} \mathrm{min}^{-1}$, then at $150^{\circ} \mathrm{C}(2$ $\min ), 280^{\circ} \mathrm{C}(5 \mathrm{~min})$ at a rate of $8^{\circ} \mathrm{C} \mathrm{min}^{-1}$; split $30: 1$ during 1.50 
min, carrier gas He: $1 \mathrm{ml} \mathrm{min}{ }^{-1}$, constant flow; sample volume $1 \mu \mathrm{l}$. To identify the parts was based on comparison of their mass spectra with those of Wiley and Nist Tutore Libraries (Adams, 2001).

\section{Insect cultures}

Rice Weevil, S. oryzae were obtained from laboratory cultures kept in the dark in incubators at $28 \pm 2^{\circ} \mathrm{C}$ and 70 to $80 \%$ relative humidity. The insects were reared on whole wheat grains at first 13 to $14 \%$ moisture content in a plastic container under the laboratory conditions at $28 \pm 2^{\circ} \mathrm{C}, 75 \pm 5 \%$ R.H. and a photoperiod of L12:D12 . The subcultures and the tests were carried out under the same conditions. Adult of $S$. oryzae, 7 to 14 days old were used for the experiments. For showing colonies of T. urticae (Koch) in the laboratory, individuals of adult females of the mite were collected from castor been, leaves ( $R$. communis L.) while first adults $A$. craccivora (Koch.) from squash leaves (Cucurbita pepo L.) at Zagazig region, Egypt. Adult females of the mite and adult aphid were reared in the laboratory on kidney bean (Phaseolus vulgaris L.) plants grown in pots $(12 \times 10 \mathrm{~cm})$ and maintained at $28 \pm 2^{\circ} \mathrm{C}$, $75 \pm 5 \%$ R.H and a photoperiod of 16:8 (L:D). A. craccivora (Koch) and $T$. urticae (Koch), one-day-old adults were used.

\section{Fumigant toxicity bioassay}

\section{S. oryzae}

A $2.0 \mathrm{~cm}$ diameter filter paper (Whatman, No.2) was placed on the underside of the screw cap of a glass vial measuring $2.5 \mathrm{~cm}$ diameter, $5.5 \mathrm{~cm}$ height, and $24 \mathrm{ml}$ volume. Ten micro liters of the volatiles $(0.00,0.30,0.15,0.075,0.037$ and $0.0187 \%)$ were added to the filter paper. The solvent was allowed to evaporate for $15 \mathrm{~s}$ before the cap was placed tightly on the glass vial, containing 20 insects, to form a sealed chamber. Dichloromethane was used as a control. Six replicates were used in all treatments and control and they were incubated at $28 \pm 2^{\circ} \mathrm{C}$ and 70 to $80 \%$ relative humidity for $24 \mathrm{~h}$. Mortality was determined $24 \mathrm{~h}$ after treatment. Results from all replicates were subjected to probit analysis using the EPA probit analysis program.1.1.3 to determine $\mathrm{LC}_{50}$.

\section{A. craccivora and T. urticae}

Glass Petri plates $(12 \mathrm{~cm}$ in diameter) were used as a mitechamber for to determine volatile phase effect of F.sycomorus leaves. Ten adult of the same age from the stock colonies of $A$. craccivora and $T$. urticae (female) was transferred individually onto excised kidney bean (Phaseolus vulgaris L.) leaves ( $3 \mathrm{~cm}$ diameter) placed with its dorsal side on wet filter paper in a Petri dish using a soft paintbrush and allowed to settle for half an hour before exposure to the volatile phase of $F$. sycomorus leaves. The filter paper was saturated with sterile distilled water. The top of the mitechamber was covered by using the other half of the Petri plate. Different concentrations of the volatile parts of $F$. sycomorus leaves were prepared at the concentrations of $0.0,0.60,0.30,0.15,0.075$ and $0.0375 \%$. The method of application of the volatile parts of $F$. sycomorus leaves, which aimed to prevent a direct contact between the mites or aphid and the volatile phase, has been described by Soylu et al. (2006). The volatile parts of $F$. sycomorus leaves were applied by micropipette on filter paper disks. The disks were previously placed on the inner surface of the inverted lid of the Petri dish, which were placed $20 \mathrm{~mm}$ from the center of the plate in order to prevent direct contact with the volatile phase. Plates were sealed immediately with paraffin to prevent loss of volatile phase from the plates. Three replications were made for each concentration. As an untreated control, three Petri dishes containing only $10 \mu \mathrm{l}$ of dichloromethane were used. The treated mite-chambers were returned to the incubator set at $28 \pm 2^{\circ} \mathrm{C}, 65 \pm 2 \% \mathrm{RH}$ and a photoperiod of 16:8 (L:D) h. Mortality was determined under a binocular light microscope $24 \mathrm{~h}$ after treatment. Probit analysis was used to determine lethal concentrations $\left(\mathrm{LC}_{50}\right.$ and $\left.\mathrm{LC}_{90}\right)$, by using the program, version 1.1.3. Abbott's formula was used to correct mortality in controls.

\section{Contact toxicity bioassay}

\section{S. oryzae}

The contact effect of volatile parts from $F$. sycomorus leaves against pest was evaluated on filter paper discs $(9 \mathrm{~cm}$ in diameter) which were treated with fumigants diluted dichloromethane. The filter papers were placed in glass Petri dishes $(9 \mathrm{~cm}$ in diameter). The aliquot of $10 \mu \mathrm{l}$ of volatile parts was applied to the filter paper discs, and the same aliquot of dichloromethane was applied to control evaluation. Volatile parts were carried out at the concentrations of $0.0,0.30,0.15,0.075,0.037$ and $0.0187 \%$ for 24 $h$ with six replicates of each control and treatment. The dichloromethane was allowed to evaporate for $10 \mathrm{~min}$ before the introduction of 20 adults in a Petri dish and these were kept in controlled temperature and humidity chamber at $28 \pm 2^{\circ} \mathrm{C}, 65 \pm 5 \%$ $\mathrm{RH}$. The death insects was counted $24 \mathrm{~h}$ after the application. Results from all replicates were subjected to probit analysis using the EPA probit analysis program.1.1.3 to determine $\mathrm{LC}_{50}$.

\section{A. craccivora and T. urticae}

A leaf-dipping method (Park et al., 2002) was used to evaluate the activity of the test samples. For adulticidal of the samples against $A$. craccivora and $T$. urticae, disks $(5.4 \mathrm{~cm}$ diameter) of kidney bean (Phaseolus vulgaris L.) leaves (two weeks after germination) were used. Test samples were carried out at the concentrations of 0.0 , $0.60,0.30,0.15,0.075$ and $0.0375 \%$. Three leaf disks per concentration were separately dipped in each test solution for $30 \mathrm{~s}$. Solvents were evaporated under a fume hood for $10 \mathrm{~min}$. Ten adults of $A$. craccivora and ten adult female of $T$. urticae was transferred individually on treated and controled (disks treated with only dichloromethane) leaf disks placed in Petri plates. All treated samples were maintained at $28 \pm 2^{\circ} \mathrm{C}, 65 \pm 2 \% \mathrm{RH}$ and a photoperiod of $16: 8$ (L: D). Mortality was determined $24 \mathrm{~h}$ after the application. Results from all replicates were subjected to probit analysis using the Environmental Protection Agency (EPA) probit analysis program.1.1.3 to determine $\mathrm{LC}_{50}$.

\section{Repellent activity bioassay}

\section{S. oryzae}

The area preference test described by McDonald et al. (1970) was used to evaluate repellent action of $S$. oryzae. Test areas consisted of $9 \mathrm{~cm}$ filter paper No. 1 that was cut two parts. In the first part a concentration of $0.1,0.01$, and $0.001 \%$ of volatile parts from $F$. sycomorus leaves was applied as possible as uniformly with a micropipette. The other part (control) was only treated with $10 \mu \mathrm{l}$ of dichloromethane. Both the treated part and the control part were air dried to evaporate the solvent. A full disc was carefully remade by attaching the treated part to the control part with adhesive paper tape. Each filter paper was placed in a Petri dish and 20 adults of $S$. oryzae were released in the center of each filter paper disc and covered. Each treatment was replicated five times. Number of insects on both treated (NT) and untreated halve (NC) were 
Table 1. Compositions and Percentages of Volatiles from F. sycomorus leaves.

\begin{tabular}{|c|c|c|c|}
\hline Peak & Retention time (min) & Compounds & Area $(\%)$ \\
\hline 1 & 5.74 & $\mathrm{~N}$-ethyl-1, 3 dithioisoindoline & 0.89 \\
\hline 2 & 6.81 & 3-hexen-1-ol, (Z) & 0.48 \\
\hline 3 & 15.84 & Benzene methanol & 1.59 \\
\hline 4 & 20.06 & L- linalool & 1.04 \\
\hline 5 & 20.37 & 1-methylbicyclo [4.1.0] heptanes 1-methylnorcarane) & 1.06 \\
\hline 6 & 26.07 & salicylic acid methyl ester & 0.73 \\
\hline 7 & 26.42 & 1, 3- cyclohexadiene-1-carboxaldehyde, 2, 6, 6-trimethyl & 0.82 \\
\hline 8 & 27.80 & 1-cyclohexene-1- carboxaldehyde & 0.71 \\
\hline 9 & 41.14 & Alpha- ionone & 0.59 \\
\hline 10 & 44.66 & 3- buten- 2-one, 4-(2, 6, 6-trimethyl-1-cyclohexen-1-yl) & 2.08 \\
\hline 11 & 45.70 & Pentadecane & 0.50 \\
\hline 12 & 46.17 & Cycloheptasiloxane,tetradecamethyl & 1.38 \\
\hline 13 & 46.88 & $2(4 \mathrm{H})$ - benzofuranone, 5, 6, 7, 7a-tetrahydro-4, 4,7a-trimethyl & 0.46 \\
\hline 14 & 49.61 & 3-hexen-1- ol, benzoate, $(Z)$ & 4.57 \\
\hline 15 & 50.00 & Megastigmatrienone & 0.46 \\
\hline 16 & 51.03 & 3- hexadecene, (Z) & 0.40 \\
\hline 17 & 53.99 & Methyl jasmonate & 0.94 \\
\hline 18 & 55.81 & Silane & 0.89 \\
\hline 19 & 63.94 & $\begin{array}{l}\text { 4-(3, 4-dimethoxybenzylidene) - 1- (4- nitro phenyl)- } \\
\text { 3-phenyl-2-pyrzolin 5-one - 3- phenyl -2-pyrazoline- 5-one }\end{array}$ & 0.68 \\
\hline 20 & 65.49 & 2- pentadecanone & 1.27 \\
\hline 21 & 66.05 & Hexadecanoic acid, methyl ester & 0.49 \\
\hline 22 & 66.85 & n-Hexadecanoic acid & 7.67 \\
\hline 23 & 68.69 & Z, Z-3, 13- octadecadien-1-ol & 1.31 \\
\hline 24 & 69.02 & 9- octadecenoic acid (Z), methyl ester (methyl oleate) & 2.41 \\
\hline 25 & 69.71 & oleic acid & 4.30 \\
\hline 26 & 69.90 & $1 \mathrm{H}$-pyrazole, 4-nitro & 5.13 \\
\hline 27 & 70.93 & palmetoyl chloride & 0.44 \\
\hline 28 & 71.18 & cyclohexene & 1.03 \\
\hline 29 & 71.42 & 5- heptadecenal & 0.56 \\
\hline 30 & 72.11 & piperidine & 0.78 \\
\hline 31 & 72.69 & Hexanedioic acid & 4.15 \\
\hline 32 & 72.87 & 9- octadecenoic acid (Z)- 2-hydroxy-1-(hydroxymethyl) ethyl ester & 1.79 \\
\hline 33 & 74.30 & 1, 2-benzenedicarboxilic acid, diisooctyl ester & 45.06 \\
\hline
\end{tabular}

recorded after $24 \mathrm{~h}$. Percent repellency $(\mathrm{PR})$ values for the test was computed as $\mathrm{PR}=[(\mathrm{NC}-\mathrm{NT}) /(\mathrm{NC}+\mathrm{NT})] \times 100$ (Obeng-Ofori and Reichmuth, 1997).

\section{A. craccivora and T. urticae}

The repellency of volatile parts from $F$. sycomorus leaves at 0.1 , 0.01 and $0.001 \%$ against $A$. craccivora and $T$. urticae, were assessed. Leaf discs of kidney bean were placed in Petri-dishes lined with moist cotton wool. Half of each disc was painted with the proper concentration, while the other left untreated. Twenty females of $A$. craccivora and $T$. urticae was placed separately of the midrib. Orientation of $A$. craccivora or $T$. urticae on treated or control half was recorded after $24 \mathrm{~h}$ from the beginning of the experiment, also the number of eggs laid on the control versus the treated half was counted after $24 \mathrm{~h}$. The percentage of repellency value was calculated.

\section{Statistical analyses}

The significance of the data was evaluated by the ANOVA one way test.

\section{RESULTS AND DISCUSSION}

\section{Chemical composition of $F$. sycomorus leaves}

The bioactive phytochemicals of $F$. sycomorus leaves were analyzed by using hydrodistillation and GC-MS. The results revealed 33 compounds representing $96.66 \%$ of the constituents (Table 1 and Figure 1). According to the analysis results, seventeen compounds represented $86.78 \%$ of the total mass of the bioactive parts were 


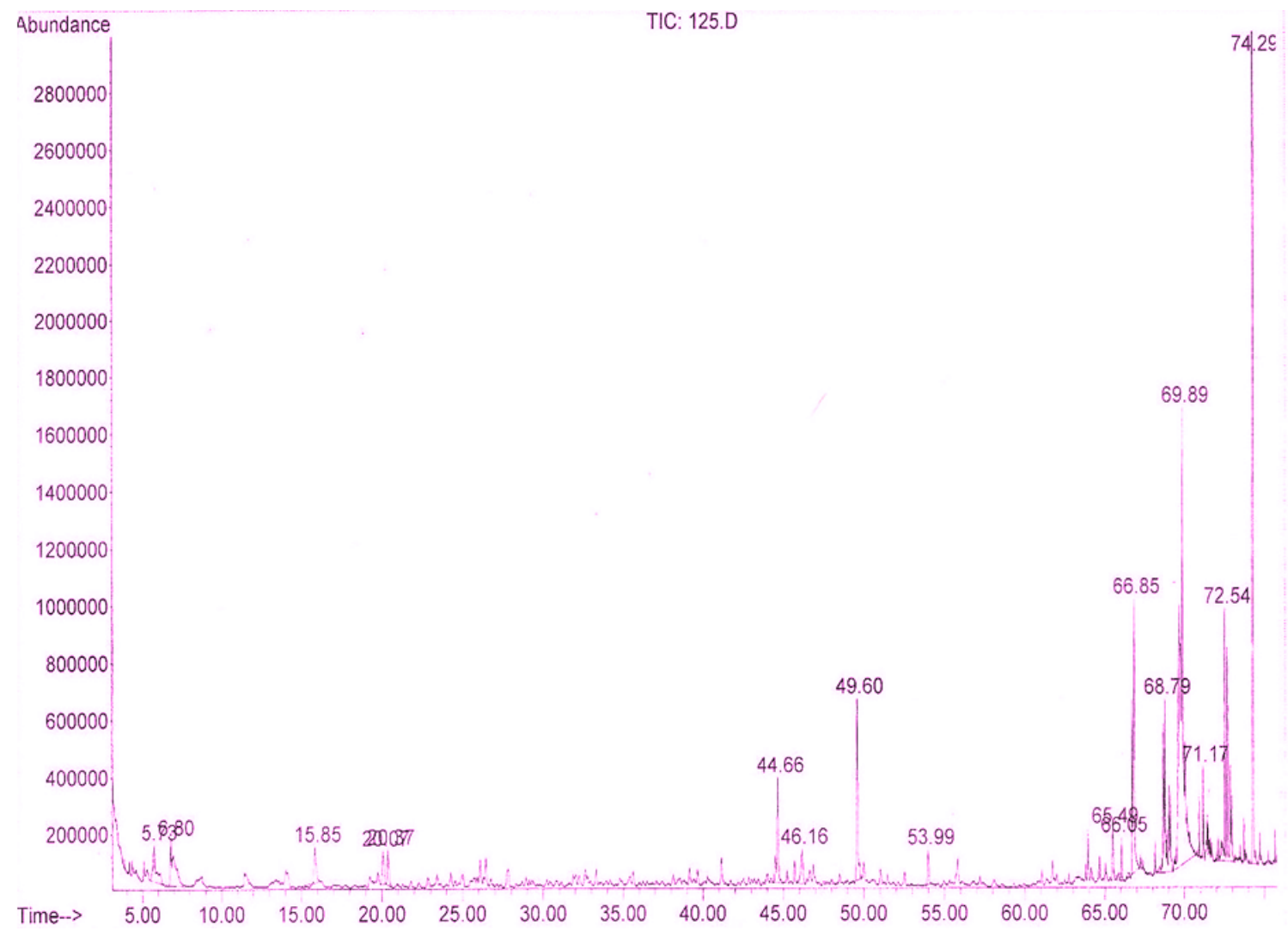

Figure 1. GC-MS volatiles chromatogram of $F$. sycomorus leaves.

identified as main parts. 1, 2-benzenedicarboxilic acid, diisooctyl ester $(45.06 \%)$ was the most plentiful part of the volatiles in F. sycomorus leaves. Other main parts of the volatiles were found to be n-Hexadecanoic acid (7.67), 1H-pyrazole,4-nitro (5.13), 3-hexen-1- ol, benzoate,Z (4.57), oleic acid (4.30), hexanedioic acid bis (2-ethyl hexyl) ester (4.15), methyl oleate (2.41), 3buten- 2-one, 4-(2, 6, 6-trimethyl-1-cyclohexen-1-yl) (2.08), 9- octadecenoic acid (Z)- 2-hydroxy-1(hydroxymethyl) ethyl ester (1.79), benzene methanol (1.59), Cycloheptasiloxane, tetradecamethyl (1.38), Z, Z3, 13- octadecadien-1-ol (1.31), 2- pentadecanone (1.27), 1-methylbicyclo [4.1.0] heptanes 1-methylnorcarane (1.06), L- linalool (1.04), cyclohexene (1.03) and Methyl jasmonate (0.94). The identified compounds have many biological properties. For instance, 1, 2benzenedicarboxilic acid, diisooctyl ester $(45.06 \%)$ was the most plentiful part of the volatiles in $F$. sycomorus leaves possesses antimicrobial activity (Ushadevi, 2008; Senthilkumar et al., 2011; Shafaghat et al., 2012).

1,2-Benzenedicarboxylic acid, di-isooctyl ester was present in Caesalpinia sappan ethanol extract (Sarumathy et al., 2011), in the ethanolic extract of the stem bark of Schleichera oleosa (51.15\%), in Dipteracanthus patulus (9.89) (Gopalakrishnan et al., 2011 ) in the marine isolates of $P$. lividum and $T$. lignorum
(Ushadevi, 2008). These compounds (BTG 504 and BTG $505)$, identified as napthoquinones, are effective against a range of commercially important pests including the tobacco whitefly, Bemisia tabaci, aphids and the twospotted spider mite, T. urticae (Khambay et al., 1999). Nhexadecanoic acid- palmitic acid (7.67) can be an antioxidant, hypocholesterolemic, nematicide, pesticide, lubricant (Praveen kumar et al., 2010). The major parts identified from Euphorbia hirta include hexadecanal, nhexadecanoic acid was observed to have repellent against Anopheles species and thus useful for malaria control (Modupe et al., 2009). Hexadecanoic acid and 9octadecenoic acid (Z), methyl ester - Oleic acid ester are known to have potent antibacterial and antifungal (Seidel and Taylor, 2004). Oleic acid in concentrations as low as $0.7 \%(\mathrm{v} / \mathrm{v})$ has been found to be fungistatic against a wide of moulds and yeasts (Sheba et al., 1999). 1Hpyrazole, 4-Nitro $(5.13 \%)$ is one among the seventeen compounds of the present study. Pyrazoles belong to one of the most important classes of heterocyclic compounds, which are significant for medicinal chemistry (Hoo et al., 2007).

Molecules of many modern drugs, e.g., antiphlogistic, antifungal, antidiabetic, and analgesic, as well on insectacaricide used in practice, contain a pyrazole ring as a fragment (Bildirici et al., 2007). The pyrazole ring 
Table 2. Toxicity of volatiles from F. sycamores leaves against S. oryza, T. urtica and A. craccivora.

\begin{tabular}{llccccc}
\hline Insect & Life stage & LC $_{50}(\%)$ & $\begin{array}{c}95 \% \text { confidence } \\
\text { limits }\end{array}$ & LC $_{90}(\%)$ & $\begin{array}{c}95 \% \text { confidence } \\
\text { limits }\end{array}$ & Slope \pm SE \\
\hline Contact toxicity & & & & & & \\
\hline S. oryzae & Adults & $0.054^{\mathrm{c}}$ & $0.01-0.12$ & $0.668^{\mathrm{c}}$ & $0.22-837.8$ & $1.17 \pm 0.45$ \\
A. craccivora & Adults & $0.213^{\mathrm{b}}$ & $0.13-0.42$ & $1.035^{\mathrm{b}}$ & $0.49-9.37$ & $1.87 \pm 0.51$ \\
T. urtica & Adults & $0.350^{\mathrm{a} * \star}$ & $0.01-0.12$ & $3.424^{\mathrm{a} * \star *}$ & $0.89-9216.9$ & $1.29 \pm 0.48$ \\
& & & & & \\
Fumigant toxicity & & & & & & \\
S. oryzae & Adults & $0.027^{\mathrm{c}}$ & $0.001-0.05$ & $0.313^{\mathrm{b}}$ & $0.13-94.02$ & $1.21 \pm 0.48$ \\
$\begin{array}{l}\text { A. craccivora } \\
\text { T. urtica }\end{array}$ & Adults & $0.084^{\mathrm{b}}$ & $0.05-0.12$ & $0.233^{\mathrm{c}}$ & $0.15-0.60$ & $2.90 \pm 0.72$ \\
\hline
\end{tabular}

${ }^{* * * H i g h ~ s i g n i f i c a n c e . ~}$

has been shown to be the basic for a few antibacterial substances (Adnan et al., 2009). Hexadenoic acid has earlier been reported as a part in alcohol extract of the leaves of Kigelia pinnata (Grace et al., 2002) and Melissa officinalis (Sharafzadeh et al., 2011). Parasuraman et al. (2009) identified 17 compounds with $n$-Hexadecanoic acid and Octadecanoic acid as the major compounds in the leaves of Cleistanthus collinus. GC-MS analysis of ethyl acetate extract of Goniothalamus umbrosus revealed the presence of $n$-Hexadecanoic acid (Siddig et al., 2009). N-hexadecanoic acid, Hexadecanoic acid and 9, 12 - Octadecadienoic acid was identified in the ethanol leaf extract of Aloe vera (Arunkumar and Muthuselvam, 2009) and Vitex negundo (Praveen kumar et al., 2010). GC-MS of Pyrenacantha staudtii leaves showed the presence of tetradecanoic acid (22\%) and hexanoic acid (13\%) as insecticidal against Rhyzopertha dominica and Tribolium castaneum, respectively (Abiodun et al., 2009). Devi et al. (2009) reported that Euphorbia longan leaves mainly contained n-hexadecanoic acid and 9, 12Octadecadienoic acid. Hexadecanoic acid (51.55), 1,2 Benzenedicarboxylic acid, bis (2-ethylhexyl) ester (20.19) and 1,2-Benzenedicarboxylic acid, dibutyl ester (2.32) from Senna italica subsp. were found to be more effective against adults of Hyalomma marginatum rufipes as antitick (Magano et al., 2008). Several plant essential oils and plant extracts contain several different bioactive compounds that may act individually, additively or in synergy to pest control (Viuda-Martos et al., 2010). It has been recognized that some plant-derived insect-control agents could be developed into products suitable for integrated pest management because they are high effectiveness, selective to pests, have no or little harmful affect against nontarget organisms or the environment (Jiang et al., 2007). These reports are by the result of this study.

\section{Insecticidal and acaricidal}

The bioactive phytochemicals effects of different concentrations of $F$. sycomorus leaves on the mortality of adults S. oryzae, A. craccivora and adult females of $T$. urticae are shown in Table 2. Data showed a highly toxic effect to all the tested insects. Volatile parts were found to cause a gradual increase in mortality with an increase in the concentration between 0.018 and $0.3 \% \mathrm{H}$. However, $100 \%$ adult mortality of $S$. oryzae, A. craccivora and $T$. urticae were recorded at $0.4 \%$ and above levels at $24 \mathrm{~h}$ of treatment. From the Table 2 it can be seen that, volatiles from $F$. sycomorus leaves was significantly more toxic to $S$. oryzae than $A$. craccivora and $T$. urticae as fumigant and contact toxicity tests. In fumigant toxicity assays, volatiles of $F$. sycomorus leaves were the most toxic one tested for $S$. oryzae where the $\mathrm{LC}_{50}$ and $\mathrm{LC}_{90}$ values were 0.027 and $0.313 \%$ followed by 0.084 and $0.233 \%$ for $A$. craccivora, then 0.129 and $0.376 \%$ for $T$. urticae . In contact toxicity assays, the corresponding $\mathrm{LC}_{50}$ and $\mathrm{LC}_{90}$ values were recorded 0.054 and $0.668 \%$ for S. oryzae, 0.213 and $1.035 \%$ for A. craccivora, 0.350 and $3.424 \%$ for $T$. urticae, respectively. At $L_{50}$, the bioactive phytochemicals from $F$. sycomorus leaves was 4.47fold more toxic to $S$. oryzae and 1.53 fold more toxic to $A$. craccivora than that of $T$. urticae as a fumigant activity, respectively. The corresponding $\mathrm{LC}_{50}$ were 6.48 fold more toxic to $S$. oryzae and 1.64 fold more toxic to $A$. craccivora than that of $T$. urticae as a contact, respectively. Volatiles from the $F$. sycomorus leaves were reported to be more toxic to all three insects as the fumigant toxicities than the contact toxicities. Probit analysis showed that at $\mathrm{LC}_{50}$, the bioactive components were 2.0 fold more toxic to $S$. oryzae, 2.54 fold more toxic to $A$. craccivora and 2.71 more toxic to $T$. urticae as a fumigant test than that of contact test. The matching $\mathrm{LC}_{90}$ were 2.13 fold more toxic to $S$. oryzae, 4.44 fold more toxic to $A$. craccivora and 9.33 more toxic to $T$. urticae as fumigant toxicities than that of contact toxicities. The contact and fumigant toxicities of various monoterpenes and how activity varies with structure was investigated. Our results clearly confirm the volatile parts from $F$. sycomorus leaves or their interaction possess insecticidal effectiveness against $S$. oryzae, $A$. cracccivora and acaricidal against $T$. urticae. Although many studies have 
Table 3. Mean percent repellency (PR) values of volatile phase from F.sycomorus leaves against $S$. ory zae, $T$. urtica and $A$. craccivora.

\begin{tabular}{|c|c|c|c|}
\hline & $0.10 \%$ & $0.01 \%$ & $0.001 \%$ \\
\hline Insects & $\begin{array}{l}\text { Percent repellency } \\
\text { (Mean \% } \pm \text { S.D) } 24 \mathrm{~h}\end{array}$ & $\begin{array}{l}\text { Percent repellency } \\
\text { (Mean \% } \pm \text { S.D) } 24 \mathrm{~h}\end{array}$ & $\begin{array}{l}\text { Percent repellency } \\
\text { (Mean \% } 1 \text { S.D) } 24 \text { h }\end{array}$ \\
\hline Sitophilus oryzae & $35.3 \pm 7.64$ & $19.0 \pm 3.61$ & $5.3 \pm 1.53^{b}$ \\
\hline Tetranychus urtica & $80.0 \pm 4.51$ & $43.0 \pm 2.51$ & $23.0 \pm 2.08^{a}$ \\
\hline Aphis craccivora & $42.0 \pm 2.52$ & $20.0 \pm 1.73$ & $0.00^{c}$ \\
\hline Significantly & N.S. & N.S. & $\star * \star$ \\
\hline
\end{tabular}

N.S. NO significance, ${ }^{* * *}$ High significance.

shown the contact or fumigant efficacy gained from several plants against different insects and mite species (Santos et al., 2011), until, no published data were available on the efficacy of volatiles from $F$. sycomorus leaves as insecticidal and acaricidal against $S$. oryzae, $A$. craccivora and $T$. urticae. The insecticidal and acaricidal of volatiles from $F$. sycomorus leaves is attributed mainly to its major compounds. Each of the volatile parts has its own contribution on biological activity against the tested insect. The bioactive phytochemicals from the $F$. sycomorus leaves were reported to be more toxic to all the three insects as the fumigant toxicities than the contact toxicities. Volatile compounds of many plant extracts and essential oils are composed of alkanes, alcohols, aldehydes and terpenoids, monoterpenoids (Visser, 1986). Many of them show the fumigant (Ahn et al., 2006). Focus on the vapor or fumigant toxicity of essential oils of plants and their constituents has sharpened since the 1980s. Plant essential oils and their constituents almost have higher boiling points and such plant products that show insect toxicity in the vapor state have been recently reviewed by Rajendran and Sriranjini (2008). The volatile phases of the essential oils were reported to be more toxic than the contact phase to the microorganisms (Soylu et al., 2006). The mode of action of the tested botanical extracts may be largely attributable to its fumigant action (Park et al., 2003). T. urticae was more susceptible to the Piper oil by fumigation than by contact (Ma'rio et al., 2012). Toxicity in the fumigation bioassays most likely was attributed to penetrate the oil vapors in the respiratory (Ma'rio et al., 2012). The insecticidal varied with insect species, oil concentrations, exposure time and chemical composition of the oil, which in turn depends on the source, season and ecological conditions, method of extraction, time of extraction and plant part used (Lee et al., 2001). Akhtar and Isman (2004) showed that Zanthoxylum alatum was the most potent as a feeding deterrent and repellent, and also caused the highest mortality of Pieris brassiceae larvae.

\section{Repellency}

The bioactive parts from F. sycomorus leave showed repellent against adults $S$. oryzae, $A$. craccivora and adult females of $T$. urticae at the concentrate $0.1,0.01$ and $0.001 \%$ (Table 3 ). The test concentrations were found repellent to adult females of $T$. utricae, followed by $A$. craccivora and $S$. oryzae, respectively. Repellency increased when the concentrations were increased. Obviously $T$. urticae females preferred nontreated areas over treated areas. Volatile constituent's evidence was significant at $0.001 \%$ for three insects while the repellency not statistically different at $0.1,0.01 \%$ (Table 3). Some monoterpenes such as a-pinene, cineole, eugenol, limonene, terpinolene, citronellol, citronellal, camphor and thymol are common constituents of a few essential oils described in the literature, as presenting insect repellent (Sammour et al., 2011; Tayoub et al., 2012). Our results clearly confirm the volatile parts from $F$. sycomorus leaves or their interaction possess insecticidal effectiveness against $S$. oryzae, $A$. cracccivora and acaricidal against $T$. urticae.

\section{Conclusion}

In conclusion, The volatiles from $F$. sycomorus leaves have a wide range of insecticidal and acaricidal and could become an alternative to synthetic pesticides for using in agro-industries and to screen and develop such novel types of selectors and natural pesticides in the biocontrol of many agricultural plant insects and mites causing drastic losses to crops.

\section{ACKNOWLEDGEMENTS}

The author is most grateful to the laboratory staff of pesticides analysis and environmental pollution Laboratory, Department of Plant Production, Faculty of Technology and Development, Zagazig University, Zagazig, Egypt.

\section{REFERENCES}

Abiodun F, Siraj R, Muhammad IC (2009). GC-MS Analysis of Insecticidal Leaf Essential Oil of Pyrenacantha Staudtii Hutch and Dalz (Icacinaceae). Trop. J. Pharm. Res. 8:139-143. 
Adams RP (2001). Identification of essential oil components by Gas Chromatography/Mass Spectrometry. Allured Publishing Corp. Illinois USA.

Adnan A, Hayam B, Ashour M, Alaa El-Din AB, Hamdy MA, Salma AB (2009). Synthesis of some pyrazolyl benzenesulfonamide derivatives as dual anti-inflammatory antimicrobial agents. J. Enz. Inhib. Med. Chem. 24:296-309.

Ahn YJ, Kim SI, Kim HK, Tak JH (2006). Naturally occurring house dust mites control agents: development and commercialization. In: Rai M, Carpinella MC (eds) Naturally occurring bioactive compounds. Elsevier, London. pp. 269-289.

Akhtar Y, Isman MB (2004). Comparative growth inhibitory and antifeedant effects of plant extracts and pure allelochemicals on four phytophagous insect species. J. Appl. Entomol. 128:32-38.

Arunkumar S, Muthuselvam M (2009). Analysis of Phytochemical constituents and antimicrobial activities of Aloe vera L. against clinical pathogens. World J. Agric. Sci. 5:572-576.

Aslan I, Ozbek H, Calmasur O, SahInn F (2004). Toxicity of essential oil vapours to two greenhouse pests, Tetranychus urticae Koch and Bemisia tabaci Genn. Ind. Crops Prod. 19:167-173.

Bildirici I, Sener A, Tozlu I (2007). Further derivatives of 4-benzoyl-1, 5diphenyl-1H pyrazole-3-carboxylic acid and their antibacterial activities. Med. Chem. Rev. 16:418-426.

Chang MS, Yang YC, Kuo YC, Kuo YH, Chang C, Chen CM, Lee TH (2005). Furocoumarin glycosides from the leaves of Ficus ruficaulis Merr. var. antaoensis. J. Nat. Prod. 68:11-13.

Cosimi S, Rossi E, Cioni PL, Canale A (2009). Bioactivity and qualitative analysis of some essential oils from Mediterranean plants against stored product pests: evaluation of repellency against Sitophilus zeamais Motschulsky, Cryptolestes ferrugineus (Stephens) and Tenebrio molitor (L.). J. Stored Prod. Res. 45:25-132.

Devi P, Nagarajan M, Christina AJ, Meera R and Merlin NJ (2009). GCMS analysis of Euphorbia longan leaves. Int. J. Pharm. Res. Dev. 8:1-4.

Fletcher J, Bender C, Budawle B, Cobb WT, Gold SE, Ishimaru CA, Luster D, Melcher U, Murch R, Scherm H, Seen RC, Sherwood JL, Sobral BW, Tolin SA( 2006). Plant pathogen forensics: capabilities needs, and recommendations. Microbiol. Mole. Biol. Rev. 70:450471.

Gao W, Lam W, Kaczmarek C, Baker DC, Cheng YC (2004). Novel mode of action of tylophorine analogs as antitumor compounds. Cancer Res. 64:678-688.

George L, Lawrences M (1961). Taxonomy of Vascular Plants. Macmillan Co New York. pp. 462-466.

Gopalakrishnan S, Saroja K, Dulcy Elizabeth J (2011). GC-MS analysis of the methanolic extract of the leaves of Dipteracanthus patulus (Jacq.) Nees. J. Chem. Pharm. Res. 3:477-480.

Grace OM, Light ME, Lindsey KL, Moholland DA, Staden JV Jader AK (2002). Antibacterial activity and isolation of antibacterial compounds from fruit of the traditional African medicinal plant, Kigelia africana. S. Afr. J. Bot. 68:220-222.

Holcapek M, Lisa M, Jandera P, Kabatova N (2005). Quantitation of triacylglycerols in plant oils using HPLC with APCI-MS, evaporative light-scattering, and UV detection. J. Sep. Sci. 28:1315-1333.

Hoo SK, Sung HK, Jae NK (2007). Expeditious Synthesis of 1,3,4 Trisubstituted Pyrazoles from Baylis-Hillman Adducts. Bull. Korean Chem. Soc. 28:1841.

Jiang JG, Huang XJ, Chen J, Lin QS (2007). Comparison of the sedative and hypnotic effects of flavonoids, saponins and polysaccharides extracted from Semen Ziziphus jujube. Nat. Prod. Res. 21:310-320.

Khambay BPS, Batty D, Cahill M, Denholm I (1999). Isolation characterization and biological activity of nephthoqionones from Calceolaria andina L. J. Agric. Food Chem. 47:770-775.

Kordali S, Cakir A, Ozer H, Cakmakci R, Kesdek M, Mete E (2008). Antifungal, phytotoxic and insecticidal properties of essential oil isolated from Turkish Origanum acutidens and its three components, carvacol, thymol and p-cymene. Bioresour. Technol. 99:8788-8795.

Lee S, Lee BH, Choi WS, Park BS, Kim JG, Campbell BC (2001). Fumigant toxicity of volatile natural products from Korean spices and medicinal plants towards the rice weevil, Sitophilus oryzae (L). Pest Manage. Sci. 57:548-553.
Li Y, Fang H, Xu W (2007). Recent advance in the research of flavonoids as anticancer agents. Mini Rev. Med. Chem. 7:663-678.

Liu ZL, Ho SH (1999). Bioactivity of the essential oil extracted from Evodia rutaecarpa Hook $\mathrm{f}$. et Thomas against the grain storage insects, Sitophilus zeamais Motsch. and Tribolium castaneum (Herbst). J. Stored Prod. Res. 35:317-328.

Ma'rio JC, Cla'udio AG, Fla'via SB, Marcílio MM, Ce'sar AB (2012). Acaricidal activity and repellency of essential oil from Piper aduncum and its components against Tetranychus urticae. Exp. Appl. Acarol. 57:139-155.

Magano SR, Thembo KM, Ndlovu SM, Makhubela NF (2008). The antitick properties of the root extracts of Senna italica subsp. Arachoides. Afr. J. Biotechnol. 7(19):476-481.

McDonald L, Guy R, Speirs R (1970). Preliminary evaluation of new candidate materials as toxicants, repellents and attractants against stored product insects. Marketing research report. P. 882.

Modupe O, Wesley O, Edith O, Osibote AE (2009). Analysis of the essential oil from the dried leaves of Euphorbia hirta Linn (Euphorbiaceae), a potential medication for asthma. Afr. J. Biotechnol. 8:7042-7050.

Navia-Gine' WG, Yuan JS, Mauromoustakos A, Murphy JB, Chen F, Korth KL (2009). Medicago truncatula (E)-b-ocimene synthase is induced by insect herbivory with corresponding increases in emission of volatile ocimene. Plant Physiol. Biochem. 47:416-425.

Obeng-Ofori D, Reichmuth C (1997). Bioactivity of eugenol, a major component of essential oil of Ocimum suave (Wild.) against four species of stored-product Coleoptera. Int. J. Pest. Manage. 43:89-94.

Palumbo J, Tickes B (2001). Cowpea aphids in Alfalfa in Yuma County farm notes. University of Arizona, Arizona.

Parasuraman S, Raveendran R, Madhavrao C (2009). GC-MS analysis of leaf extracts of Cleistanthus collinus Roxb. (Euphorbiaceae). Int. J. Ph. Sci. 1:284-286.

Park BS, Lee SE, Choi WS, Jeong CY, Song C, Cho KY (2002). Insecticidal and acaricidal activity of piperonaline and piperoctadecalidine derived from dried fruits of Piper longum L. Crop Prot. 21:249-251.

Park IK, Lee SG, Choi DH, Park JD, Ahn YJ (2003) Insecticidal activities of constituents identified in the essential oil from leave of Chamaecyparis obtuse against Callosobruches chinensis (L.) and Sitophilus oryzae (L.). J. Stored Prod. Res. 39:375-384.

Pontes WJT, Oliveira JCS, Camara CAG, Lopes ACHR, Gondim MGC, Oliveira JV, Schwartz MOE (2007). Composition and acaricidal activity of the resin's essential oil of Protium bahianum Daly against two spotted spider mite (Tetranychus urticae). J. Essent. Oil Res. 19:379-383.

Praveen KP, Kumaravel S, Lalitha C (2010). Screening of antioxidant activity, total phenolics and GC-MS study of Vitex negundo. Afr. J. Biochem. Res. 4:191-195.

Rajendran S, Sriranjini V (2008). Plant products as fumigants for stored product insect control. J. Stored Prod. Res. 44:126-135.

Safia Z, Aoumeur B (2011). Chemical composition and insecticidal properties of some aromatic herbs essential oils from Algeria. Food Chem. 129:179-182.

Sammour EA, Fatma MA, Nahid FA (2011). Comparative study on the efficacy of neemix and basil oil formulations on the cowpea aphid Aphis craccivora Koch. Arch. Phytopathol. Plant Prot. 44:655-670.

Santos JC, Faroni LRA, Sousa AH, Guedes RNC (2011). Fumigant toxicity of allyl isothiocyanate to populations of the red flour beetle Tribolium castaneum. J. Stored Prod. Res. 47:238e243.

Sarumathy K, Vijayayakanthia T, Dhana RMS (2011). A Protective effect of Caesalpinia sappan (CS) on acetaminophen induced Nephrotoxicity and oxidative stress in male albino rats. J. Pharmacol. Toxilcol. 1:11-21.

Seidel V, Taylor PW (2004). In-vitro activity of extracts and constituents of Pelagonium against rapidly growing mycobacteria. Int. J. Antimicrobial. Agents. 23:613-619.

Senthilkumar G, Madhanraj P, Panneerselvam A (2011). Studies on the Compounds and Its Antifungal Potentiality of Fungi Isolated From Paddy Field Soils of Jenbagapuram Village, Thanjavur District, and South India. Asian J. Pharm. Clin. Res. 1:19-21.

Shafaghat A, Farshid S, Vahid mani-Hooshyar A (2012). Phytochemical and antimicrobial activities of Lavandula officinalis leave and stems 
against some pathogenic microorganisms. J. Med. Plants Res. 6:455460.

Sharafzadeh S, Morteza K-K, Javidnia K (2011). Aroma Profile of Leaf and Stem of Lemon Balm (Melissa Officinalis L.) Grown under Greenhouse Conditions. Adv. Environ. Biol. 5:547-550.

Sheba DW, Saxena RK, Gupta R (1999). The fungistatic action of oleic acid. Curr. Sci. 76:1137-1139.

Siddig IA, Ahmad BA, Manal ME, Syam MI, Mohamed YM, Abdelbasit A, Alhaj NA, Rasedee A (2009). GC-MS determination of bioactive components and antibacterial properties of Goniothalamus umbrosus extracts. Afr. J. Biotech. 8:3336-3340.

Soylu EM, Soylu,S, Kurt S (2006). Antimicrobial activities of the essential oils of various plants against tomato late blight disease agent Phytophthora infestans. Mycopathologia 161:119-128.

Tayoub G, Amer A, Rlyad G (2012). Fumigant activity of leaf essential oil from Myrtus communis L. against the Khapra Beetle. Int. J. Med. Arom. Plants. 2:207-213.

Teixeira DM, Patao RF, Coelho AV, da Costa CT (2006). Comparison between sample disruption methods and solid-liquid extraction (SLE) to extract phenolic compounds from Ficus carica leaves. J. Chromatogr. A 1103:22-28.

Ushadevi T (2008). Studies on the microfungal in the muthupet mangroves with emphasis on antimicrobial activity. Ph.D. Thesis, Trichirappalli, India: Bharathidasan University.

Van Noort S, Gardiner AJ, Tolley KA (2007). New records of Ficus (Moraceae) species emphasize the conservation significance of inselbergs in Mozambique. South Afr. J. Bot. 73:642-649.

Visser JH (1986). Host odor perception in phytophagous insects. Annu. Rev. Entomol. 31:121-144.
Viuda-Martos M, Ruiz-Navajas Y, Fernandez-Lopez J, Perez-Alvarez JA (2010). Effect of adding citrus fibre washing water and rosemary essential oil on the quality characteristics of a bologna sausage. LWT - Food Sci. Technol. 43:958-963.

Wittstock U, Gershenzon J (2002). Constitutive plant toxins and their role in defense against herbivores and pathogens. Curr. Opin. Plant Biol. 5:300-307.

Ye J, Zhao M, Liu J, Liu.W (2010). Enantioselectivity in environmental risk assessment of modern chiral pesticides. Environ. Poll. 158:23712383.

Zhang Z (2003). Mites of Greenhouses: Identification, Biology and Control, CABI Publishing, Wallingford. Jepson, L.R., H. 18:54-61. 